\title{
FACTORS WHICH MOTIVATE MUSIC TEACHERS' TRAINING IN THEIR WORKING ENVIRONMENT
}

\section{BUKANTAITÉ Daiva, KUBILIŪTĖ Monika}

Vytautas Magnus University, Kaunas, Lithuania

\begin{abstract}
Aim of the study was to identify the factors that motivate teachers 'learning in their work environment Participatory photography method is the kind of method where the participants of the research reply to the questions of the researcher by taking photographs. Later, the photographs are defined, explained and analyzed, while sharing the insights with the researcher. Every participant of the research was contacted prior to the research by telephone or e-mail. They were asked to take photographs of the factors that motivate them to study in their workplace; the time of the interview was arranged also. Some participants of the research invited the researchers to their schools because they wanted to take the pictures right before the interview. Others came to the interview with pictures they have already taken. 10 music teachers, who work at their institution for not less than three years, were chosen for the research. After the teachers submitted their photographs, they were asked a few main questions: Why did you take a photograph of this particular phenomenon? Why does it motivate you to learn in your work environment? How do you learn? Why do you learn in your workplace? Every research participant was personally introduced to the goal of the research and got their questions answered. Participation was voluntary. To endure the confidentiality of the participants, they were not asked to provide any personal or other kind of information that would help to identify them. The research was limited by the fact that the teachers represented different institutions and worked with students of different age, that is why only common tendencies were distinguished, no comparison or evaluation was performed. Findings: three groups of factors that encourage learning in a workplace were identified: evaluation (taking part in projects, competitions, received awards); functional (information technology use, workplace, tools (course books, traditional and untraditional instruments); structural (colleagues, students, going to concerts, trips, taking part in master classes). Conclusion: Teachers do not link "workplace", only with their work in class. Going to concerts, taking part in seminars, projects, student preparation for competitions, trips were also mentioned as learning factors. Teachers' learning in their workplace is encouraged by their desire to improve in their professional work, confidence in themselves and their opportunities, desire to feel good in their work environment.
\end{abstract}

Keywords: Learning; Music teachers; Music training; School. 
$\frac{\text { DE }}{G}$

DE GRUYTER

OPEN

DOI: 10.1515/arhss-2015-0004 Applied Research in Health and Social Sciences: Interface and Interaction, Vol. 12, No. 1, 2015

\section{Background}

Teachers who adjust to the pace of life, technology, who are interested in becoming a part of a creative and innovative society, are truly appealing. When developing a learning society, educational institutions are the ones that change the orientation of people, from one based on teaching, to one, based on learning, which allows to develop the qualities and competences of the members of organizations (Simonaitienė, 2007).

The idea of a school community that is capable of learning is active. Schools can be recreated, turned into more lively ones and constantly renewed not only by commands or rules but by orienting themselves to learning. It means that every person should become a part of the system and also has an ability to express their personal desires, improve their knowledge and abilities. In a learning school community, everyone understands their own value as well as the benefits of learning from each other (Senge 2008). Žydžiūnaite and others second the author's opinion (2012) by noticing that employees in the organizations are only eager to improve when they are led by personal / individual factors, like a desire to become more professional, realization of their lack of competences, ambition to manage personal „,ignorance“ and justify confidence, a wish to be as qualified as the others. Music teachers are directly responsible for the musical erudition of the young generation, which also makes them responsible for the musical culture of the country. That is why it is very important that music teachers would always keep on learning and improving. The importance of the role of a teacher in today's school is linked to huge responsibilities and fostering of competences like ability to learn, information management, problem solving. (Lasauskienè, 2010). Constant learning, a need to renew and improve own competences, is emphasized in all teacher training documents.

The relevance of the research is anticipated by the lack of ability to identify learning in a workplace, which is one of the teachers' learning forms. The problem of the research is formulated in question: what factors encourage teachers to learn in their workplace? The object of the research: the factors that encourage teachers' learning in the work environment. The aim of the research was to identify the factors that encourage the teachers' learning in their work environment. The authors of the research think that the identification of the factors that encourage teachers ${ }^{6}$ learning in their workplace will allow to make an assumption that the participatory photography method is the right method to measure learning in an organization. 


\section{Methodology}

\section{Sample}

The participants of the research are selected by using the convenience principle. The participants are teachers of high-schools, gymnasiums, music schools and pre-music schools, who work in their institution for not less than three years. The geographical spectrum of the participants of the research takes up the territory of Lithuania. The search for participants happened in various ways: by asking acquainted teachers, their colleagues, sending invitations via e-mails, given in the official websites of various schools. After contacting the teachers, the research was presented to them and they were asked to participate. 10 teachers took part in the research: nine women and one man. 4 of the teachers work in gymnasiums, 1 works in a music school, 3 - in a high-school, 1 in a middle school and pre-school and 1 in pre-school. While describing the results of the research, the participants of the research are coded from P1 to P10.

\section{Methods}

Participatory photography method is a method where the participants of the research have to answer the researcher's questions by taking photographs. Later on, the photographs are described, explained and analyzed, personal insights are shared with the researcher (Wuggenig, 1990). Kolb (2008) draws attention to the importance of the participant in the process of the participatory photo interview. Active participation of the participant of the research is what distinguishes the participatory photography method from using professional photographs in scientific research. Participatory photography method is different from participatory research method because the researchers are not committed to propose improvement plans for the researched area, as they are supposed in the second (Poviliūnas, 2003).

Firstly, every participant was contacted by phone or e-mail and was asked to take pictures of factors that encourage them to learn in their workplace. They were asked to make as many pictures as possible and the time and place of the interview was set. While trying to avoid any influence for the participants of the research (Valentine, 1999) and questions like „,what should I photograph?“ or „,what did other people photograph?" and other questions like these, the researchers didn't take part in the process of taking pictures. Some of the participants invited the researchers to their schools because they wanted to take pictures right before the interview. When these cases occurred, the researchers waited while the participants took pictures of their chosen objects and only then performed the interviews. All the pictures were made by participants` own photo cameras or cell phones. 


\section{DE DE GRUYTER

DOI: 10.1515/arhss-2015-0004 Applied Research in Health and Social Sciences: Interface and Interaction, Vol. 12, No. 1, 2015

Eight interviews were performed at schools, where the participants work, one - before the concert of the students of one of the teachers in the Culture Center, one - in a university. The interview took place in about 2 weeks after the participants agreed to take part in the research. During the interview, the teachers were asked to show their photographs (they were all printed) and asked to assemble schemes (pictures) of learning in their work environment.

\section{Tool}

The teachers were asked a few questions while interviewing:

- Why did you take this exact picture?

- What is in the picture?

- Why does it encourage you to learn in your work environment?

- How do you learn?

- Why do you learn in a workplace?

Some additional questions were asked when needed, if they occurred naturally during the conversation. Photographs and stories that came along with them, were used for the research (Kolb, 2008), special attention was paid to external and internal factors acknowledged by the participants during the process of taking pictures and telling their stories (Banks, 2001). Photographs of separate participants were not compared; no one tried to find differences and similarities between them.

\section{Ethics}

Every research participant was personally introduced to the goal of the research and their questions were answered. The participants took part in the research voluntarily. In order to ensure their confidentiality, the participants were not asked to present any personal information, which would make it possible to identify them. The participants took care of the parents consents to take pictures of their children during the research. Colleagues that got to be in the pictures didn't mind it and were informed by the participants about the future uses of the photographs.

\section{Findings}

According to the teachers that took part in the research, their learning in their workplace is encouraged by various factors. Some were mentioned by a few participants, others were only stressed by some. Open master classes, which are open to everyone who is interested, were mentioned by a few teachers. These 
DOI: 10.1515/arhss-2015-0004 Applied Research in Health and Social Sciences: Interface and Interaction, Vol. 12, No. 1, 2015

classes usually take part at the school and are attended by an invited teacher or performer and the students of the school.

These lessons are really beneficial for the teachers because we improve our professional knowledge that determines our successful professional work. In the open lessons professional teachers share their teaching and learning experiences, reveal ways and methods that we can use in our lessons later ( $\mathrm{P} 1)$.

A very pleasant way of learning is going to concerts.

While being at a concert you can hear new forms of performing, you can also hear the melodies that you forgot or haven 't even heard yet. Concerts form musical taste and erudition. Going to concerts helps to know the variety of current musical world, puts one in an optimistic mood, inspires for new activities, encourages new ideas about teaching children the art of music (P8).

A very important learning process, which requires professional knowledge and skills, is student preparation for competitions, festivals and concerts. Places won in competitions and invitations to take part in festivals are visible results of this work.

Achievements in competitions motivate everyone, preparations improve relationships. If you don 't take part in anything, you will not be interesting to anyone (P9).

Possibilities provided computers and other technologies were mentioned by most of the participants. The teachers highlighted the following aspects:

i) listening to records -

Listening to records helps to know the variety of ways of performing, to see and to hear unique instruments of the world, musical traditions, to choose the correct interpretations for teaching/learning (P1).

ii) tracking new trends -

Internet allows us to update our musical knowledge. We can learn about the newest musical technologies, lives and works of various musicians. Music videos, records of famous orchestras, allow us to know, see and hear things for ourselves (P2).

iii) preparation for lessons -

When I search for information for children, I find and learn things myself. It makes me even more interested in the music world. My desire for learning resonates with the students. They find out where to look for interesting and useful musical things online (P4).

iv) computer technologies used during the lessons -

With the help of multimedia, the lessons become more visual and, of course, more useful, because the students can watch videos, play electronic/virtual instruments. The learning happens faster (P3).

v) particular computer programs - 
DOI: 10.1515/arhss-2015-0004 Applied Research in Health and Social Sciences: Interface and Interaction, Vol. 12, No. 1, 2015

Sheet music writing programs allowed me to change the quality of lessons. The students write music during the lessons and with the help of multimedia, everyone can watch (P3).

vi) communication online -

The teachers had to learn to use electronic diaries and communication programs. They also had to learn to form their thoughts correctly, when they write notes for the parents. Since we all want to be understood correctly and state our thoughts clearly. Communication with the parents is a constant process of learning (T6).

The teachers also took pictures of course books and other books that they use during the lessons. Music teachers can choose the course book they want and work according to it. In this process, it is very important that the course book would be useful for both the teacher and the students. While talking about course books, the teachers highlighted some characteristics:

i) presentation of the material -

The tasks are presented in a way that encourages the students' creativity and develops their emotional imitation. The course books encourage me and teach me to see music lessons differently, more creative (P3).

ii) Mastering of the material -

When teaching the students by using course books, firstly, we learn ourselves. The theories that we learn have to be told in other words, than the ones used in the course books, because they are not always clear for the students. They need examples, it helps them master the course material (P6).

iii) Schools, which have enough material resources have the musical instruments, but the music teachers often only know how to play the piano. Yet, other instruments are also considered to be a learning factor:

There are various instruments in our school and my desire, as a music teacher, is to be able to play all of them in order to teach the children to play them as well. All music instruments encourage personal and professional improvement of the teacher. We play and learn together (T5).

iv) One of the teachers that took part in the research mentioned untraditional instruments.

I am very interested in untraditional instruments, I look for them online and in seminars. I learn to make them and to play them. After I learn myself, I teach the children. The students love interesting, unseen and at the same time, very primitive but special, instruments, that are really fun to play. Untraditional instruments need different sheet music than usual. It takes a lot of work to learn these subtleties (P3).

v) Participation in projects was mentioned as yet another form of learning in the work environment.

My school has creative partnership project, where students, teachers and parents learn together by creating. Teachers learn to form critical, meaningful questions in groups. Those questions will help to accomplish goals, set by creative partnerships, when working with classes, where the children have 
DOI: 10.1515/arhss-2015-0004 Applied Research in Health and Social Sciences: Interface and Interaction, Vol. 12, No. 1, 2015

problems with communication, motivation, behavior culture, discipline (P7).

Teachers mentioned contemporary and comfortably equipped workplace, which ensures quality of the lesson, and allows expansion of the professional knowledge by using computer, internet, listening to records by using quality hardware.

Definitely not all teachers mentioned students as a factor that encourages learning in a workplace (which was expected by the researchers). When talking about the students, the teachers highlighted:

i) Spontaneity -

The students are the best learning "sources" for the teachers. They always have new, enlightening ideas. Youthful spontaneity of the students encourages interest in new things (P5).

ii) General work -

I can clearly state that I get most of my knowledge from my students. They are my main "tool" of learning in my workplace. The process of learning together is important as well. All the events, concerts for the parents and performances are the result of the work that we do together (P6).

iii) Acquired knowledge -

The students go to music schools, play various instruments, they have ideas and suggestions that they are not afraid to share. I am glad that these students form the majority in my school (P7).

It is interesting that many participants mentioned diplomas that they received. Photographs of concerts of their students were used as a proof of professional development and a stimulus for achieving better results.

Teachers mentioned trips as a learning factor:

I like spending time with the students in an informal environment. They become more open. It helps me work with them (P6).

Only a few teachers mentioned colleagues as a learning factor:

I learn the most from my colleagues. They are always benevolent and open to new things. I can always ask them for help (P9).

\section{Reflection on findings}

When the teachers were invited to take part in the research, at first they all showed the same reaction they all stated that they do not learn at school. So the research allowed us to witness that the participatory photography method encouraged the teachers to think about learning in their workplace. After the teachers agreed to take part in the research, a time of constant communication and new experiences began. It is very interesting that the conversations, during which the teachers were asked to take part in the research was extremely different from the ones, during which the teachers already had their 
photographs. During these conversations, the teachers became open story tellers and told about their work. The objects and people that appeared in the photographs, helped the participants reveal and understand how and from whom they learn.

All the conversations started as formal ones and ended up being very cozy. Every interview is an experience for the researchers, an opportunity to get acknowledged with the culture of the schools, the rules and teachers' experiences. Different teachers showed different motivation. Some learn from the books they have at school, others use information technologies and play instruments because they have to, because the authorities of the school bought them and demand that to use them. Other teachers that took to part in the research, initiate buying new gear themselves, while aiming for more interesting and more attractive lessons. The results showed that material resources of the class are not directly connected to teachers' learning in their workplace. It is strange that only a few of the participants mentioned students as a learning factor. Researchers think that students are one of the most important factors for teachers' learning in the workplace. The teachers that mentioned students stressed the everyday communication process but not the increasing and changing effects of the students and their improvement (especially in the IT sector).

One of the teachers that took part in the research didn't understand the task. She stated that she doesn't learn at school because she had already learned everything she needs. Yet she photographed children and the tools that she uses in her lessons. Not many teachers photographed their colleagues. Only one teacher acknowledged them as the main learning factor. Some mentioned the competition they feel at school, which stands in the way of communication. On the one hand, teachers are professionally alike since they do the same work - they teach children, play instruments and live in the world of sounds, on the other hand, every participant was individual. Everyone has their own beliefs and understanding about what and how they are supposed to learn and teach. For some, the most important thing in a lesson is singing, for others its playing the instruments or creativity encouragement, the outlooks are different as well as skills and desire to teach and learn.

\section{Conclusions}

The use of participatory photography method helps to identify the factors that encourage the learning in a workplace and the reflection of the participants of the research. Three groups of factors that encourage learning in a workplace were identified: i) evaluation (taking part in projects, competitions, received awards); ii) functional (information technology use, workplace, tools (course books, traditional and 
untraditional instruments); iii) structural (colleagues, students, going to concerts, trips, taking part in master classes).

Teachers do not link "workplace", only with their work in class. Going to concerts, taking part in seminars, projects, student preparation for competitions, trips were also mentioned as learning factors. Teachers' learning in their workplace is encouraged by their desire to improve in their professional work, confidence in themselves and their opportunities, desire to feel good in their work environment. A link between active participation in the learning process, the acknowledgment of this process and creativity of the students, was witnessed.

\section{References}

Banks, M. (2001). Visual Methods in Social Research. London: Sage.

Ellis, A., \& Dryden, W. (1998). The Practice of Rational Emotive Behavior Therapy. New York: Springer Publishing.

Kolb, B. (2008). Involving, Sharing, Analysing-Potential of the Participatory Photo Interview. Available at http://www.qualitative-research.net/index.php/fqs/index (Retrieved on 08/04/2014).

Lasauskienè, J. (2010). Muzikos mokytojo veikla ir kompetencijos. Vilnius: VPU leidykla

Poviliūnas, A. (2003) Tyrimas dalyvaujant kaip socialinių inovacijų technologija. Sociologija, 1, $42-49$.

Senge, P. (2008). Besimokanti mokykla. Vilnius: Versa/The book.

Simonaitienè, B. (2007). Mokyklos - besimokančios organizacijos vystymas. Kaunas: Technologija

Valentine, G. (1999). Being seen and heard? The ethical complexities of working with children and young people at home and at school. Ethics, Place and Environment, 2(2), 141-154.

Žydžiūnaite, V., Lepaite, D., Cibulskas, G., \& Bubnys, R. (2012). Savaiminis mokymasis darbo aplinkoje: bendrosios kompetencijos vystymosi kontekstualumas (socialinio ir sveikatos priežiūros sektoriu, formalios savivaldos ir nevyriausybiniu organizacijų atvejai). Šiauliai: ŠVK leidykla.

Wuggenig, U. (1990). Die Photobefragung als projektives Verfahren. Angewandte Sozialforschung, 16(1/2), 109129. 